\title{
RESOLUTIONS ADOPTED
}

\author{
A. BY THE GENERAL ASSEMBLY \\ SUMMARY OF DECISIONS CONTAINED IN THE REPORT OF \\ THE GENERAL ASSEMBLY
}

I. Statutes and By-laws. The revised Statutes and By-laws, as adopted, are printed on pages 477 in Part 6.

2. Structure of Commissions. A revised structure was adopted for Commissions.

3. Admission of Countries. The action of the Executive Committee in admitting Taiwan as an Adhering Country was confirmed. It was announced that the Executive Committee had also admitted: Brazil, North Korea, and Turkey.

4. The International Latitude Service. The resolution submitted by the International Union of Geodesy and Geophysics was adopted. It was noted that the Executive Committee had accepted the offer from the Science Council of Japan to set up the Central Bureau at Mizusawa under the directorship of Dr. T. Hattori.

5. The Unit of Contribution. It was agreed to increase the unit of contribution for the years I 962 , I 963 and 1964 from 500 to 600 gold francs.

6. Budget of Expenditure. In accepting the Budget, as proposed by the Finance Committee (see page 39), the General Assembly approved those financial resolutions from Commissions for which provision is made. These resolutions are not repeated here.

7. Advisory Finance Committee. It was agreed to discontinue this committee.

8. Commissions and Sub-Commissions. It was agreed that:

(a) Commission 3 (Notations) be dissolved;

(b) Commission 14 be renamed "Commission on Fundamental Spectroscopic Data";

(c) Commission 28 be renamed "Commission on Galaxies";

(d) Sub-Commission 29 a become Commission 36 on "The Theory of Stellar Atmospheres";

(e) All other Sub-Commissions become Committees or Working Parties of their main Commissions.

RESOLUTION NO. I

Proposed by the Executive Committee

Viewing with great concern the grave danger that some future space projects might seriously interfere with astronomical observations in the optical as well as in the radio domain, 
persuadée qu'un degré de pollution de l'espace, à peine décelable actuellement, pourrait, s'il était durable, se révéler un jour désastreux pour les observations utilisant des techniques perfectionnées,

affirmant qu'aucune collectivité n'a le droit de modifier sensiblement l'espace au voisinage de la Terre, sans un accord international fondé sur une enquête approfondie,

l'Union Astronomique Internationale insiste tout particulièrement pour que soient pris en considération les progrès futurs de l'astronomie, qu'il y aurait de graves inconvénients moraux et matériels à perdre de vue,

et demande instamment à tous les gouvernements engagés dans les expériences spatiales qui pourraient affecter la recherche astronomique, de prendre l'avis de l'Union Astronomique Internationale avant d'entreprendre de telles expériences et de ne procéder à aucun lancement sans qu'il soit établi d'une manière irréfutable qu'aucun dommage ne peut en résulter pour la recherche astronomique.

\section{RÉSOLUTION NO. 2}

\section{Proposée par le Comité Exécutif}

L'Union Astronomique Internationale constate avec satisfaction que les plans du projet West Ford ont été annoncés publiquement bien avant l'époque du lancement projeté et que, selon les intentions officielles* du Gouvernement des Etats-Unis, au sujet des expériences suivantes, de tels projets ne seront pas entrepris sans que des assurances suffisantes aient été obtenues qu'elles ne compromettront pas gravement les observations astronomiques.

Cependant, l'Union Astronomique Internationale considère avec la plus grande inquiétude le cas où la ceinture de dipôles qui fait l'objet du projet West Ford serait de longue durée et reste résolument opposée à cette expérience jusqu'à ce que le problème de la permanence ait été clairement exposé dans des publications scientifiques, un délai suffisant étant laissé pour son étude. L'Union Astronomique Internationale reste opposée aux expériences qui pourraient empêtrer les développements futurs dans l'astronomie.

S'il peut être prouvé que les dipôles auront une vie courte et que l'expérience ne présente aucun inconvénient, et si l'expérience West Ford est entreprise, l'Union Astronomique Internationale considère comme essentiel que les observations et les expériences les plus complètes sur les propriétés et le comportement de la ceinture de dipôles soient entreprises par tous les moyens possibles. Ces observations et ces expériences devront être exécutées et analysées au niveau scientifique le plus élevé et avec le meilleur équipement disponible, en considérant que des signaux à peine, ou non, décelables aujourd'hui pourraient compromettre gravement les recherches entreprises dans la suite avec des moyens de sensibilité accrue.

Il est probable que ces observations et ces expériences seront difficiles à exécuter, et seront à maints égards identiques à celles que les autorités responsables du projet entreprendront à l'occasion de l'opération West Ford. En outre, beaucoup de données, telles que des éphémérides précises et tenues à jour, seront nécessaires. L'Union Astronomique Internationale s'efforcera d'organiser une coopération rapide et efficace entre les observateurs et les calculateurs, et d'assurer la diffusion mondiale de leurs résultats conformément à l'usage en matière de recherche scientifique.

L'Union Astronomique Internationale apprend avec satisfaction que les décisions* du Gouvernement des Etats-Unis, relatives aux expériences ultérieures du type West Ford, seront

* Lettre du 11 août 1961, du Dr. J. B. Wiesner au Dr. L. V. Berkner 
and believing that a degree of contamination of space which at the present time would be hardly detectable, might, if long-lived, well be disastrous to future observations with improved techniques,

and maintaining that no group has the right to change the Earth's environment in any significant way without full international study and agreement;

the International Astronomical Union gives clear warning of the grave moral and material consequences which could stem from a disregard of the future of astronomical progress,

and appeals to all Governments concerned with launching space experiments which could possibly affect astronomical research to consult with the International Astronomical Union before undertaking such experiments and to refrain from launching until it is established beyond doubt that no damage will be done to astronomical research.

RESOLUTION NO. 2

\section{Proposed by the Executive Committee}

The International Astronomical Union expresses its appreciation that the plans for Project West Ford have been publicly announced well ahead of proposed launching and of the United States Government's official policy* that further launchings will be guided by the principle that such projects shall not be undertaken unless sufficient safeguards have been obtained against harmful interference with astronomical observations.

Nevertheless the International Astronomical Union views with the utmost concern the possibility that the band of dipoles proposed in Project West Ford might be long-lived, and it is completely opposed to the experiment until the question of permanence is clearly settled in published scientific papers with adequate time being allowed for their study. The International Astronomical Union is opposed to any experiment which might hamper future developments in astronomy.

If a short lifetime for the dipoles and the harmless nature of the experiment can be assured, and if Project West Ford is carried out, the International Astronomical Union regards it as essential that the fullest observations of, and experiments on, the properties and behaviour of the band of dipoles be carried out by all possible means. The observations and experiments should be performed and analysed according to the highest scientific standards and with the best equipment available, bearing in mind that signals which are barely, or not, detectable today will probably cause serious interference with future scientific research because of the development of more sensitive equipment.

The observations and experiments to be made on West Ford are likely to be difficult to perform, and will, in many ways, be similar to those carried out by the authorities responsible for operating West Ford. Moreover, much specific information such as precise and up-to-date ephemerides will be required. The International Astronomical Union will attempt to arrange for rapid and full co-operation among astronomers making observations and calculations, and to provide for world-wide dissemination of their results conforming to accepted standards of scientific research.

The International Astronomical Union welcomes the position* taken by the Government of the United States that any decision on later experiments of the West Ford type will be taken in

* Letter of August 11, 1961, from Dr. J. B. Wiesner to Dr. L. V. Berkner 
prises à la lumière des résultats de l'expérience actuellement en projet. Pour lui permettre de réunir les données nécessaires, l'Union Astronomique Internationale prie le Gouvernement des Etats-Unis de donner tous pouvoirs à un groupe d'astronomes agréé à la fois par le Gouvernement et par l'Union, pour coopérer avec les autorités West Ford en vue de déterminer par des expériences quantitatives les propriétés de la ceinture de dipôles, ses variations dans le temps et l'espace, et ses répercussions sur les recherches astronomiques présentes et futures.

$$
\text { RÉSOLUTION NO. } 3
$$

\section{Soumise par l'UIGG et proposée par la Commission 19}

\section{L'Union Géodésique et Géophysique Internationale}

\section{Recommande}

(I) qu'un accroissement des ressources financières du Bureau Central du Service International des Latitudes (SIL) soit fait,

(2) que les Stations du Service des Latitudes de l'hémisphère Nord continuent leur activité avec les instruments actuels et en apportant quelques améliorations à leur équipement, parce que la nécessité de coordonnées précises du pôle, à la fois pour les buts astronomiques et géodésiques, est plus grande que jamais,

(3) que le SIL soit réorganisé en un Service International du Mouvement du Pôle, qui utilisera à la fois les observations d'heure et de latitudes faites aussi bien dans les stations indépendantes que dans celles du SIL,

(4) qu'un groupe de travail restreint soit créé initialement pour établir un plan définitif pour l'organisation de la coopération internationale dans l'étude du mouvement du pôle et ensuite pour diriger le travail dans l'avenir. Le groupe devra soumettre à l'UAI des recommandations concernant l'emplacement futur du Bureau Central du SIL (à devenir SIMP),

(5) que l'on publie les coordonnées du pôle sous la forme

$$
x=x_{0}+x_{1}, y=y_{0}+y_{1}
$$

où $x$ et $y$ sont les coordonnées du pôle calculées à partir de latitudes moyennes initiales fixes, et $x_{1}$ et $y_{1}$ sont les coordonnées calculées à partir de la latitude moyenne de l'époque. Les coordonnées du pôle moyen de l'époque sont $x_{0}$ et $y_{0}$.

(6) que les résultats obtenus avec les instruments du SIL et avec les instruments indépendants soient publiés en détail aussitôt que possible,

(7) que les problèmes suivants soient pris en considération:

(a) réduction à un système uniforme et analyse soigneuse des données du SIL;

(b) élaboration de critères pour définir la précision des observations de latitude, et comparaison, sur la base de ces critères, des observations faites avec les différents instruments,

(8) que le champ de densité de l'atmosphère en altitude soit étudié au-dessus de chaque station, pour fixer l'ordre de grandeur des réfractions accidentelles, et qu'au moins une telle étude soit faite lors du choix d'un emplacement nouveau,

(9) que par des mesures appropriées l'équilibre de température entre l'instrument et l'air de l'abri soit assuré, et que les propriétés intrinsèques de l'instrument, pour en dépister les défauts optiques ou mécaniques, soient étudiées, 
the light of the results obtained from the presently proposed experiment. To enable the International Astronomical Union to obtain the necessary data, it requests the Government of the United States to grant full privileges to a group of astronomers, acceptable both to the Government and to the Union, to co-operate with West Ford authorities in performing quantitative experiments to determine the properties of the proposed belt of dipoles, its changes with time and location, and its impact upon present and future astronomical research.

RESOLUTION NO. 3

Submitted by IUGG and proposed by Commission 19

The International Union of Geodesy and Geophysics:

Recommends

(I) that an increase be made in the financial resources of the Central Bureau of the International Latitude Service (ILS),

(2) that the northern ILS stations should continue in operation with the present instruments, and with some improvement in their equipment, due to the fact that the need for accurate polar co-ordinates for both astronomical and geophysical purposes is greater than ever before,

(3) that the ILS be reorganized into an International Polar Motion Service utilizing both time and latitude observations made at both independent and ILS stations,

(4) that a small working group be created initially to establish a definite plan for the organization of international co-operation in the study of polar motion and then to direct the work in the future. The group should submit to the IAU recommendations concerning the future location of the Central Bureau of the ILS (to become IPMS),

(5) that the co-ordinates of the pole shall be given in the following forms:

$$
x=x_{0}+x_{1}, y=y_{0}+y_{1},
$$

where $x$ and $y$ are computed using fixed initial latitudes and $x_{1}$ and $y_{1}$ are computed using the mean latitude of epoch. The co-ordinates of the mean pole of epoch are $x_{0}$ and $y_{0}$.

(6) that results obtained with the' ILS and independent instruments should be published in detail as soon as practicable,

(7) that the following problems should be investigated further:

(a) reduction to a uniform system, and careful analysis of the data of the ILS,

(b) elaboration of criteria for the precision of latitude observations and comparison, by means of these criteria, of observations made with different instruments,

(8) that the density field in altitude of the atmosphere above each station should be studied in order to fix the order of magnitude of accidental refraction, and that as a minimum one such study be made when choosing a new location,

(9) that the necessary measures be taken to assure equilibrium in temperature between an instrument and the air of the shelter, and that the intrinsic properties of the instrument should be studied to avoid optical and mechanical faults, 
(Io) que l'on procède à une étude de détail du champ de pesanteur local, pour en déceler les anomalies éventuelles, chaque fois qu'on aura quelque raison de suspecter des variations anormales de la verticale. Une telle prospection serait utile lorsqu'on se propose de créer une station nouvelle,

(x I) qu'un astrolabe soit installé à Mizusawa,

(I2) que l'Observatoire de Quito mette en service l'astrolabe qui y a été envoyé et que l'Observatoire entreprenne la détermination de l'heure et de la latitude et l'observation d'étoiles fondamentales,

(I3) que deux autres astrolabes soient installés dans l'hémisphère Sud, pour l'étude du mouvement du pôle, de préférence dans des observatoires déjà équipés d'instruments d'astronomie de position, et encourage le projet de l'Observatoire National du Chili d'installer un de ces appareils à Santiago,

(I4) que l'Observatoire de La Plata installe un PZT sur la même latitude que celle de Mount Stromlo,

note

avec satisfaction l'assurance donnée par le Professeur Cassinis que l'activité de la station de latitude de Carloforte continuera, et souligne l'importance de cette station,

et recommande

que l'Union Astronomique Internationale considère l'adoption de cette résolution.

RÉSOLUTION NO. 4

Proposée par la Commission 14

Considérant que l'angström est égal à $10^{-10}$ mètre avec une précision aussi grande que celle avec laquelle il a été réalisé par la raie rouge du cadmium, et que, d'autre part, le mètre est maintenant défini avec une plus grande précision par la radiation $2 p_{10^{-}-5} d_{5}$ du krypton 86

l'Assemblée générale décide, pour autant que les autres Unions représentées dans la Commission Triple de Spectroscopie soient d'accord, que

(I) l'angström est défini comme étant égal à $10^{-10}$ mètre,

(2) la définition de l'angström en vigueur depuis 1907 , fondée sur la raie rouge du cadmium, est abrogée.

\section{RÉSOLUTION NO. 5}

\section{Proposée par le Comité Exécutif}

Considérant qu'il est impossible d'accorder un examen particulier à chaque résolution adoptée par chacune des $5^{8}$ Commissions et Sous-Commissions, et ayant pleine confiance dans ses Commissions,

cette Assemblée générale désire donner son accord aux résolutions adoptées par ses Commissions individuelles,

et recommande que les astronomes les rendent effectives dans toute la mesure de leurs possibilités. 
(Io) that a detailed study of the local gravity field should be made to reveal the anomalies whenever there are reasons to suspect abnormal variations of the vertical. Such a study would be useful when a new station is created.

(II) that an astrolabe be installed at Mizusawa,

(12) that the Observatory of Quito should place in service the astrolabe that has been sent there, and that the Observatory should undertake the determination of time and latitude and the observations of fundamental stars,

(13) that two other astrolobes should be installed in the southern hemisphere for the study of polar motion, preferably in observatories already equipped with position-measuring instruments, and heartily endorses the plan of the National Chilean Observatory to install an astrolabe in Santiago,

(14) that the La Plata Observatory establish a PZT at the same latitude as that of Mount Stromlo,

notes

with satisfaction the assurance given by Professor Cassinis that the activity of Carloforte latitude station will be continued, and stresses the importance of this station,

and recommends

that the International Astronomical Union consider the adoption of this Resolution.

RESOLUTION NO. 4

Proposed by Commission 14

Considering that the angstrom is equal to $10^{-10}$ meter with an accuracy as great as that with which it has been realized in terms of the red line of cadmium and that, on the other hand, the meter now is defined with a great accuracy in terms of the $2 p_{10}-5 d_{5}$ radiation of krypton 86

the General Assembly decides, subject to agreement by the other Unions represented in the Triple Commission for Spectroscopy, that

(x) the angstrom is defined as being equal to $10^{-10}$ meter,

(2) the definition of the angstrom in force since 1907 based on the red line of cadmium is revoked.

\section{RESOLUTION NO. 5 \\ Proposed by the Executive Committee}

Considering the impracticability of giving individual attention to every resolution adopted by each of its 58 Commissions and Sub-Commissions, and having full confidence in its Commissions,

this General Assembly wishes to give its endorsement to the resolutions adopted by its individual Commissions,

and recommends that astronomers give effect to these resolutions in so far as they are able. 